\title{
MENINGKATKAN HASIL BELAJAR IPS KELAS VIII SMP DENGAN PAKET PEMBELAJARAN BERBASIS MASALAH
}

\author{
Ira Arini \\ e-mail: ira.arini@gmail.com \\ Teknologi Pendidikan, Program Pascasarjana Universitas Negeri Jakarta
}

Jalan Rawamangun Muka Jakarta Timur

\begin{abstract}
Abstrak: Penelitian ini bertujuan untuk menghasilkan paket pembelajaran IPS berbasis masalah dalam proses pembelajaran di kelas VIII SMP dilengkapi dengan buku siswa, buku guru, media pembelajaran dan kumpulan evaluasi agar tujuan pembelajaran dapat tercapai secara optimal. Dilaksanakan di SMP wilayah Kecamatan Rangkasbitung, Kabupaten Lebak, Banten pada bulan September 2014 sampai dengan Mei 2015 dengan metode research and development model pengembangan Derek Rowntree. Hasil penelitian adalah produk bernama Paket Pembelajaran Aplikasi Konsep IPS yang terdiri dari: buku siswa, buku guru, media pembelajaran dan kumpulan evaluasi. Hasil evaluasi formatif: pakar, face to face tryout, dan field test menyatakan bahwa produk tersebut telah dianalisis secara keseluruhan memiliki kategori "sangat baik", sehingga menjadi produk akhir yang layak digunakan sebagai paket pembelajaran IPS berbasis masalah yang menarik, menyenangkan dan tidak membosankan.
\end{abstract}

Kata-kata Kunci: pengembangan, paket pembelajaran IPS, pembelajaran berbasis masalah.

\section{IMPROVING STUDENTS' LEARNING ACHIEVEMENT IN SOCIAL SCIENCE WITH PROBLEM-BASED INSTRUCTIONAL PACKAGE}

\begin{abstract}
The purpose of this research is to produce problem-based instructional package for Social Science Subject in Grade VIII, Junior Secondary School. The package consisted of students book, teacher's manual, instructional media, and evaluation materials. The research was conducted in Junior Secondary School in September 2014 through May 2015 in Rangkasbitung Sub-district, Lebak District, Banten applying research and development model introduced by Derek Rowntree. The research produced Instructional Package for Social Science Application consisting of students book, teacher's manual, instructional media, and evaluation materials. Formative evaluation indicated by expert review, face to face try out, and field test was 'very good'. The final product is feasible to be used as the problem-based instructional package for Social Science which is interesting, joyful and motivating.
\end{abstract}

Keywords: Keywords: development, Social Science instructional package, problem based learning

\section{PENDAHULUAN}

Mata pelajaran IPS mengarahkan peserta didik untuk dapat menjadi warga negara Indonesia yang demokratis dan bertanggung jawab, serta warga dunia yang cinta damai. Nilai-nilai ini dapat ditanamkan pada peserta didik, baik sekolah dasar maupun menengah, terutama pada usia remaja yaitu pada usia 15-21 tahun atau usia mulai kelas VIII SMP sampai universitas semester awal. Kelas VIII SMP dianggap sebagai usia yang dapat mewakili usia remaja awal untuk mendapatkan bekal nilainilai tanggung jawab terhadap hak dan kewajiban sebagai warga negara yang patuh terhadap hukum dan peraturan yang berlaku.

Mata pelajaran IPS disusun secara sistematis, komprehensif, dan terpadu dalam proses pembelajaran menuju kedewasaan dan keberhasilan dalam kehidupan di masyarakat. Dalam implementasinya, tujuan umum mata pelajaran IPS dapat dicapai dengan optimalisasi seluruh komponen pembelajaran seperti tujuan pembelajaran, peserta didik, guru, materi dan media pembelajaran, strategi, sumber belajar, serta evaluasi. Semua komponen pembelajaran ini saling berhubungan dan mempengaruhi satu sama lain sehingga dapat disebut sebagai sistem.

Komponen pembelajaran tentunya harus mencakup semua aspek, baik dari aspek pengetahuan, keterampilan, sikap, dapat dengan mudah diterapkan serta harus berhubungan dengan permasalahan yang dihadapi peserta didik dalam kehidupan seharihari di lingkungan sekitarnya. Permasalahan yang dihadapi ini tentunya dapat menjadi salah satu konteks untuk para peserta didik belajar berpikir 
kritis dan keterampilan memecahkan masalah, dan memperoleh pengetahuan. Namun, permasalahan yang dihadapi peserta didik sering kali tidak terstruktur dengan baik bahkan mereka tidak menyadari bahwa permasalahan tersebut bisa saja menjadi bahan untuk membangun pengetahuannya. Pembelajaran berbasis masalah dalam pembelajaran IPS dapat memungkinkan peserta didik untuk mengumpulkan, mengintegrasikan serta menerapkan pengetahuan baru melalui permasalahan yang dihadapi sehari-hari.

Untuk itu, diperlukan pengembangan sumber belajar berupa bahan ajar berbasis masalah dalam proses pembelajaran IPS yang dapat memungkinkan peserta didik dalam mencapai tujuan pembelajaran. Pengembangan sumber belajar ini dapat berupa paket pembelajaran yang disusun secara sistemik dan sistematis karena dilakukan validasi oleh para expert, serta evaluasi secara one to one, small group, dan field test.

Pengembang membatasi ruang lingkup dari beberapa masalah yang dikemukakan di atas pada satu masalah saja yaitu bagaimana mengembangkan paket pembelajaran IPS berbasis masalah dalam proses pembelajaran di Kelas VIII SMP sesuai dengan kebutuhan peserta didik sehingga tujuan pembelajaran dapat tercapai secara optimal. Kemudian dipersempit lagi lingkup masalahnya, yaitu cara mengembangkan dan menghasilkan pembelajaran pembelajaran IPS berbasis masalah di kelas VIII SMP.

Penelitian ini difokuskan pada bagaimana mengembangkan dan menghasilkan paket pembelajran IPS berbasis masalah untuk kelas VIII di SMP wilayah Kecamatan Rangkasbitung, Kabupaten Lebak. Paket pembelajaran dapat berupa buku siswa, buku guru, media pembelajaran, serta kumpulan evaluasi pembelajaran. Tujuan dari penelitian pengembangan ini adalah untuk menghasilkan suatu produk pembelajaran berupa paket pembelajaran IPS berbasis masalah kelas VIII SMP dan menambah sumber belajar agar tujuan pembelajaran dapat tercapai secara optimal.

Secara praktis pengembangan paket pembelajaran ini memberikan manfaat pada: (a) peserta didik, khususnya peserta didik kelas VIII SMP di kecamatan Rangkasbitung, Kabupaten Lebak dapat bermanfaat dalam memecahkan masalah belajar, memberikan solusi bahwa bahan ajar dapat menjadi sumber belajar yang dapat memenuhi kebutuhan dalam mencapai tujuan pembelajaran; (b) peserta didik lainnya yang ingin memperdalam keilmuan mengenai IPS; (c) guru, sebagai fasilitator dalam pembelajaran bermanfaat untuk lebih memaksimalkan beraneka ragam sumber belajar dalam kegiatan pembelajaran; (d) pengembang, bermanfaat untuk memberikan saran dan rekomendasi mengenai bahan ajar yang sesuai dengan kebutuhan mata pelajaran IPS Kelas VIII SMP; serta (e) SMP di wilayah kecamatan Rangkasbitung, dapat memberikan sumbangan berupa pengembangan sumber belajar berupa paket pembelajaran yang dapat diintegrasikan dalam proses pembelajaran.

Secara teoretis, pengembangan paket pembelajaran berbasis masalah ini diharapkan dapat menjadi: (a) sebagai salah satu penerapan teori yang telah didapat selama mendapat pendidikan di Jurusan Teknologi Pendidikan, (b) sebagai salah satu produk pembelajaran yang diharapkan dapat memecahkan masalah belajar, serta (c) memberikan bentuk penyajian materi pembelajaran yang menarik dan memotivasi peserta didik dan guru dalam meningkatkan hasil belajar dan kreatifitas mengajar.

Menurut Undang-Undang Republik Indonesia Nomor 18 Tahun 2002 disebutkan pengembangan adalah kegiatan ilmu pengetahuan dan teknologi yang bertujuan memanfaatkan kaidah dan teori ilmu pengetahuan yang telah terbukti kebenarannya untuk meningkatkan fungsi, manfaat, dan aplikasi ilmu pengetahuan dan teknologi yang telah ada, atau menghasilkan teknologi baru. Menurut Seels and Richey (1994), pengembangan adalah proses penerjemahan spesifikasi rancangan ke dalam bentuk fisik. Pengembangan merupakan salah satu komponen dalam definisi Teknologi Pendidikan yang terdapat dalam definisi konsep AECT 2004 dalam Molenda, dkk. (2008): "educational technology is the study and ethical practice of facilitating learning and improving performance by creating, using, managing appropiate technological processes and resources". Dari definisi yang telah disebutkan, terdapat kata "creating" yang berarti menciptakan teknologi yang tepat guna. Menciptakan teknologi yang tepat guna dalam pembelajaran bisa dalam bentuk mengembangkan beberapa komponen berupa produk, proses dan sistem. Semuanya bertujuan untuk mengatasi masalah belajar yang dihadapi oleh peserta didik agar dapat mencapai tujuan pembelajaran yang efektif dan efisien.

Menurut Khaerudin dan Rusmono (2014), pengembangan juga merupakan salah satu jenis penelitian campuran (mixed methode) karena dalam pelaksanaannya menggunakan metode yang 
relavan, seperti metode penelitian deskriptif, evaluatif dan eksperimen atau penggabungan jenis penelitian kualitatif dan kuantitatif. Richey dan Klein dalam Emzir (2012) mendefinisikan penelitian pengembangan sebagai "the systematic study of design, development and evaluation processes with the aim of esablishing an empirical basis for the creation of instructional products and tools and new or enhanced models that govern their development". Penelitian ini mengembangkan sistem instruksional yang didefinisikan oleh Reigeluth dalam Suparman (2010) sebagai tiga tahap kegiatan, yaitu: (1) desain yang bagi seorang pengembang instruksional berfungsi sebagai cetakan biru atau blue print bagi ahli bangunan, (2) produksi yang berarti penggunaan desain untuk membuat program instruksional, dan (3) validasi yang merupakan penentuan kualitas atau validitas. Reigeluth (2009) juga mengemukakan definisi dari instruksional sebagai "as anything that is done purposely to facilitate learning".

Dari definisi-definisi yang telah dijelaskan dapat disimpulkan bahwa pengembangan adalah proses kegiatan dalam meningkatkan atau mengembangkan meningkatkan fungsi, manfaat, dan aplikasi ilmu pengetahuan dan teknologi yang telah ada, atau menghasilkan teknologi baru dari spesifikasi desain ke dalam bentuk fisik. Pengembangan sistem instruksional merupakan proses yang sistematis dalam mengidentifikasi masalah, mengembangkan bahan dan strategi instruksional, serta mengevaluasi efektifitas dan efisiensinya dalam mencapai tujuan instruksional.

Model pengembangan menurut Gustafson dan Branch (1981:18) mencakup model pengembangan berorientasi kelas, produk dan sistem. Model pengembangan berorientasi kelas berada dalam lingkup yang kecil dimana guru berperan penting dalam proses pembelajaran di kelas. Sedangkan model pengembangan berorientasi produk meliputi model-model yang berfokus pada menghasilkan pembelajaran dengan produk yang spepesifik. Model pengembangan berorientasi sistem ini menghasilkan pembelajaran yang luas seperti rangkaian pembelajaran atau kurikulum. Dengan adanya sebuah model dalam pengembangan pembelajaran akan memudahkan dalam menyusun dan menerapkan langkah-langkah untuk mencapai hasil yang diinginkan dengan baik.

Salah model pengembangan berorientasi produk adalah model pengembangan Rowntree (1994). Rowntree (1994) menggagas sebuah model pengembangan bahan belajar mandiri. Menurut
Rowntree, dalam mengembangkan bahan belajar terdapat tiga tahapan, yaitu (a) tahap perencanaan, (b) tahap persiapan penulisan, serta (c) tahap penulisan dan penyuntingan. Gambar 1 berikut merupakan bagan model pengembangan pada penelitian ini yang merujuk pada model pengembangan Rowntree (1994).

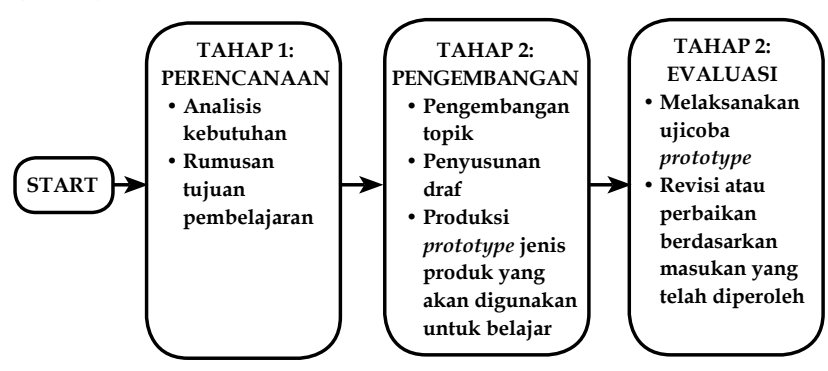

Gambar 1. Tahap model pengembangan (merujuk pada model Rowntree)

Produk yang dikembangkan dalam penelitian ini yaitu paket pembelajaran IPS berbasis masalah untuk SMP kelas VIII. Pembelajaran berbasis masalah pada mulanya diterapkan pada ilmu kesehatan di MsMaster University, Kanada pada tahun 1980 karena pada saat itu siswa tidak mampu menerapkan sebagian besar pengetahuan ilmiah mereka untuk situasi klinis.

Menurut Savin (2006:1), problem bassed learning atau pembelajaran berbasis masalah adalah sebuah metode pembelajaran yang inovatif untuk melibatkan siswa dalam pembelajaran berdasarkan masalah yang dihadapinya sehari-hari. Menurut Tan dalam Rusman (2010), pembelajaran berbasis masalah merupakan penggunaan berbagai macam kecerdasan yang diperlukan untuk melakukan konfirmasi terhadap tantangan dunia nyata, kemampuan untuk menghadapi segala sesuatu yang baru dan kompleksitas yang ada. Pembelajaran berbasis masalah dilandasi oleh beberapa teori belajar dari segi pedagogis yang merupakan proses membantu peserta didik dalam mengembangkan kapasitas untuk belajar bagaimana menghubungkan kesulitan mereka dengan teka-teki yang berguna untuk membentuk masalah. Dalam memecahkan masalah yang ada, perlu menyadari bahwa seluruh proses kognitif dan aktivitas mental terlibat di dalamnya. Otak bekerja dengan siklus tertentu dan literasi dari berpikir sistematis, sistemik, analisis general, dan divergen.

Berdasarkan teori belajar konstruktivisme, ciri pembelajaran berbasis masalah antara lain (a) pemahaman diperoleh dari interaksi dengan skenario permasalahan dan lingkungan belajar, (b) pergulatan 
dengan masalah dan proses inquiry masalah menciptakan disonansi kognitif yang menstimulasi belajar, dan (c) pengetahuan terjadi melalui proses kolaborasi negosiasi sosial dan evaluasi terhadap keberadaan sebuah sudut pandang (Siregar, dkk, 2010)

Hal pertama yang harus diperhatikan dalam merancang pembelajaran berbasis masalah adalah akar desain masalah yang riil berupa kenyataan hidup. Dalam pembelajaran berbasis masalah, sebuah masalah yang dikemukakan kepada peserta didik harus sangat membangkitkan pemahaman peserta didik terhadap masalah, sebuah kesadaran akan adanya kesenjangan, pengetahuan, keinginan memecahkan masalah, dan adanya persepsi bahwa mereka mampu memecahkan masalah tersebut. Permasalahan menjadi fokus, stimulus, dan pemandu proses belajar, sementara guru menjadi fasilitator dan pembimbing. Setelah itu, menentukan tujuan pembelajaran berbasis masalah yang berisi penguasaan disiplin ilmu dan pengembangan keterampilan pemecahan masalah.

Kurikulum dalam pembelajaran berbasis masalah dalam Rusman (2010) meliputi (1) mega level (the why), yaitu profil lulusan yang diharapkan, tujuan umum program pengetahuan, keterampilan, sikap, dan kompetensi lainnya yang menekankan pada pengembangan disiplin ilmu; (2) makro level (the what), yaitu latihan dan modul tujuan lembaga, belajar dari materi dan silabus, penilaian tujuan, struktur, kriteria, dan kegiatan evaluasi; serta (3) mikro level (the how), yaitu struktur kegiatan, jadwal sesi pembelajaran berbasis masalah, tutorial, struktur belajar mandiri, dan kemasan belajar, sumber masalah dan belajar.

Model pembelajaran IPS berbasis masalah yang digunakan dalam pembelajaran ini terdiri dari beberapa langkah. Pertama, studi kasus. Studi kasus memberikan rangsangan kepada peserta didik untuk berpikir kritis mengenai masalah yang tersirat di dalam sebuah paragraf atau ilustrasi yang diberikan. Kedua, inkuiri masalah. Peserta didik yang telah menemukan masalah pada tahap sebelumnya memulai mendeteksi dan menyusun masalah dalam urutan prioritas. Ketiga, materi pembelajaran. Langkah ini mengaitkan masalah yang ditemukan dengan materi pembelajaran yang relavan. Keempat, pemecahan masalah. Setelah menghubungkan masalah yang ditemukan dengan materi pembelajaran, peserta didik bersama-sama dengan guru diharapkan dapat memecahkan masalah. Pemecahan masalah dapat dilakukan secara individu dan kelompok, baik dalam bentuk penugasan tertulis ataupun lisan. Kelima, evaluasi dan refleksi. Tahap terakhir dalam pembelajaran IPS berbasis masalah yang berisi solusi dari masalah yang diangkat pada materi tertentu dan kesan-kesan selama melakukan langkah-langkah tersebut.

Dalam kaitannya dengan pembelajaran, paket pembelajaran adalah sejumlah komponen pembelajaran berupa bahan, alat, media, petunjuk, dan pedoman yang akan digunakan dalam proses pembelajaran. Paket pembelajaran didefinisikan oleh Pearson (2014:1) bahwa "a freely available virtual resource, designed to help country and sector level practitioners expand their knowledge and skills for facilitating sustainable capacity development". Pernyataan tersebut menjelaskan bahwa serangkaian media atau sarana yang digunakan oleh guru dan peserta didik dalam proses pembelajaran. Rangkaian ini dapat meliputi buku bahan pembelajaran untuk peserta didik, petunjuk pemanfaatan untuk guru, power point, serta kumpulan tes.

Bahan ajar atau learning material adalah bahan yang berisi informasi dan pengetahuan yang dapat digunakan oleh siswa untuk melakukan proses belajar dalam upaya mencapai kompetensi spesifik. Selain digunakan sebagai sarana utama dalam aktivitas pembelajaran, bahan ajar juga sering digunakan untuk dalam kegiatan pembelajaran yang bersifat perbaikan (remedial) dan pengayaan (enrichment). Bahan ajar tersebut biasanya berupa paket-paket pembelajaran yang terdiri dari media cetak dan non-cetak. Media cetak biasanya terdiri dari buku, modul, dan petunjuk belajar. Sedangkan media noncetak terdiri dari program audio, video, dan program berbasis komputer (computer based program).

Menurut Dick dan Carey dalam Sitepu (2012), bahan ajar yang digunakan dalam penyelenggaraan pembelajaran dapat digolongkan menjadi tiga, yaitu (a) bahan yang sudah tersedia, (b) bahan yang dapat digunakan untuk melakukan kegiatan pembelajaran, dan (c) bahan yang sengaja diproduksi untuk dapat membantu siswa dalam mencapai tujuan pembelajaran tertentu. Buku pelajaran pokok atau sering juga disebut buku wajib atau buku paket adalah buku acuan utama yang dipergunakan oleh peserta didik dan guru dalam kegiatan belajar dan membelajarkan. Buku ini memuat bahan pembelajaran yang dipilih dan disusun secara teratur untuk satu mata pelajaran.Isi buku ini merupakan bahan minimal yang harus dikuasai oleh peserta didik pada jenjang dan jenis pendidikan tertentu sesuai dengan isi kurikulum yang berlaku. 
Pengertian media pembelajaran dikemukakan oleh Gerlach \& Elly dalam Arsyad (1997), media dapat dipahami sebagai penghubung antara manusia, materi, atau kejadian yang membangun kondisi yang membuat siswa mampu memperoleh pengetahuan, keterampilan, atau sikap. Definisi lain juga dijelaskan oleh Miarso (2007) bahwa media adalah segala sesuatu yang digunakan untuk menyalurkan pesan serta dapat merangsang pikiran, perasaan, perhatian, dan kemauan pemelajar sehingga dapat mendorong terjadinya proses yang disengaja, bertujuan, dan terkendali.

Penerapan media pembelajaran dilandasi oleh teori perluasan konsep media yang mana teknologi bukan hanya sekedar benda, alat, bahan atau perkakas, tetapi tersimpul pula sikap, perbuatan organisasi, dan manajemen yang berhubungan dengan penerapan ilmu. Artinya, dalam penerapannya, media disampaikan dengan menggunakan alat ataupun bahan, serta perlu adanya manajemen dan kemampuan guru dalam mengelola pesan berupa materi pembelajaran melalui media. Media pembelajaran yang dikembangkan dalam paket pembelajaran IPS berbasis masalah ini adalah media pembelajaran articulate. Articulate adalah perangkat lunak buatan Global Incorporation, Amerika Serikat yang dikhususkan untuk mendesain media pembelajaran berbasis ICT (Kurniawan, 2015). Perangkat lunak ini dapat digunakan untuk para desainer pembelajaran dari tingkat pemula hingga tingkat ahli. Program perangkat lunak ini memiliki kelebihan, yaitu smart brainware yang sederhana dengan prosedur tutorial interaktif melalui template yang dapat dipublikasikan secara offline maupun online sehingga memudahkan pengguna untuk memformatnya dalam bentuk web personal, CD, word processing, dan Leraning Management System (LMS).

Untuk mengetahui tercapai tidaknya kompetensi, guru perlu mengadakan evaluasi setiap selesai menyajikan satu bahasan kepada peserta. Fungsi penilaian ini adalah memberikan umpan balik kepada guru dalam rangka memperbaiki proses belajar mengajar dan melaksanakan program berikutnya bagi peserta didik belum berhasil. Evaluasi menurut Gronlund (2009) adalah “... is the process of interpreting the evidence and making judgements and decisions based on the evidence". Artinya, suatu proses secara sistematis yang berguna untuk menentukan atau membuat keputusan yang dapat dijadikan indikator untuk mengetahui sejauh mana tujuan-tujuan pengajaran yang telah ditetapkan. Bentuk evaluasi yang digunakan di dalam pengembangan paket pembelajaran IPS berbasis masalah ini berupa kumpulan tes hasil belajar yang meliputi semua tujuan pembelajaran yang telah ditetapkan. Penilaian pada tes hasil belajar menurut Jihad (2012) adalah proses memberikan memberikan atau menentukan terhadap hasil belajar tertentu berdasarkan suatu kriteria tertentu. Proses pemberian tersebut berlangsung dalam bentuk interpretasi yang diakhiri dengan judgement yang merupakan tema penilaian yang mengaplikasikan adanya suatu perbandingan antara kriteria dan kenyataan dalam konteks situasi tertentu. Atas dasar itu, dalam penilaian selalu ada objek atau program, kriteria, dan judgement.

Fungsi evaluasi dalam pendidikan, yaitu (1) untuk mengetahui perkembangan dan kemajuan serta keberhasilan bagi para peserta didik setelah mengalami atau menjalani kegiatan belajar selama jangka waktu tertentu, (2) untuk mengetahui tingkat keberhasilan program pengajaran yang telah dijalankan, (3) untuk keperluan BK atau Bimbingan dan Konseling pada para peserta didik, serta (4) untuk keperluan dalam perbaikan dan pengembangan kurikulum sekolah.

Mata pelajaran IPS diSMP dan MTs merupakan salah satu mata pelajaran yang wajib ditempuh oleh siswa SMP dan MTs. IPS pada kurikulum sekolah (satuan pendidikan), pada hakikatnya merupakan mata pelajaran wajib sebagaimana dinyatakan dalam Undang-undang Nomor 20 Tahun 2003 tentang Sistem Pendidikan Nasional pada pasal 37 yang berbunyi bahwa kurikulum pendidikan dasar dan menengah wajib memuat ilmu pengetahuan sosial.

National Council for Social Studies (NCSS) dalam Michaelis (2009) mendefinisikan dan merumuskan pengertian ilmu pengetahuan sosial sebagai berikut "Social studies is the integrated study of the social sciences and humanities to promote civic competence. Within the school program, Social Studies provides coordinated, systematic study drawing upon such disciplines as anthropology, archaeology, economics, geography, history, law, philosophy, political science, psychology, religion, and sociology, as well as appropriated content from the humanities, mathematics, and natural sciences."

Pendapat senada oleh Kumari (2011) yang menjelaskan beberapa pendekatan, isi, dan maksud tentang social studies sebagai kurikulum sehingga menjadi mata pelajaran IPS, yakni: Subcjet-centered approaches argue that the Social Studies curriculum derives its content and purposes from disciplines taught in higher education. Some advocates would limit Social 
Studies curriculum ti the study of traditional history and geography while others would also include the traditional social sciences (e.g., anthropology, economics, political science, sociology, psychology). Still other would inter and multidisciplinary areas such as ethnic studies, law, women's studies, cultural studies, and gay/lesbian studies.

Berdasarkan pendapat Kumari, maka mata pelajaran IPS (social studies) tidak hanya sebatas disiplin ilmu sosial yang terdiri dari antropologi, ekonomi, geografi, sejarah, dan hukum namun dapat dikaitkan dengan berbagai multidisipliner keilmuan yang terdiri dari suku, gender, budaya, dan penyimpangan sosial. Begitu pula dengan mata pelajaran IPS yang ada di Indonesia.

Sebagaimana definisi dari NCSS bahwa mata pelajaran IPS merupakan sebuah nama mata pelajaran integrasi dari mata pelajaran sejarah, geografi, dan ekonomi serta pelajaran ilmu sosial lainnya, Michaelis (1957:2) menjelaskan dan merumuskan tentang Social Studies di tingkat sekolah adalah suatu penyederhanaan disiplin ilmu-ilmu sosial, psikologi, filsafat, ideologi negara, dan agama yang diorganisasikan dan disajikan secara ilmiah dan psikologis untuk tujuan pendidikan.

\section{METODE PENELITIAN}

Tujuan penelitian ini adalah menghasilkan paket pembelajaran IPS berbasis masalah untuk kelas VIII SMP di wilayah kecamatan Rangkasbitung, kabupaten Lebak. Penelitian ini telah dilaksanakan di tiga SMP wilayah kecamatan Rangkasbitung selama 6 minggu dengan rencana dari bulan September 2014 - Juli 2015.

Sasaran penelitian ini adalah peserta didik kelas VIII serta guru mata pelajaran IPS di SMP wilayah kecamatan Rangkasbitung. Penelitian ini dikembangkan untuk pembelajaran persiapan kemerdekaan RI, Pranata Sosial dan Masalah Kerja. Dengan adanya paket pembelajaran IPS berbasis masalah ini diharapkan dapat membantu mempercepat proses pembelajaran dan meningkatkan hasil belajar peserta didik secara efektif dan efisien.

Penelitian ini menggunakan metode penelitian dan pengembangan (Research and Development). Sebagaimana yang dikatakan oleh Borg dan Gall dalam Emzir (2012), penelitian dan pengembangan adalah suatu proses untuk mengembangkan dan memvalidasi produk-produk pendidikan. Menurut Sugiyono (2008), penelitian dan pengembangan merupakan "jembatan" antara penelitian dasar (basic research) dan penelitian terapan (applied research). Penelitian pengembangan bertujuan untuk menemukan, mengembangkan dan memvalidasi suatu produk. Penelitian pengembangan juga didefinisikan oleh Badan Penelitian dan Pengembangan Departemen Pendidikan Indonesia (2008) sebagai penelitian yang memuat 3 komponen yaitu model pengembangan, prosedur pengembangan, dan uji coba produk.

Pendekatan yang dilakukan dalam penelitian pengembangan ini adalah pendekatan pengembangan pembelajaran berorientasi kelas dan produk yang menggunakan model pengembangan Rowntree.

Penelitian ini diawali dengan mengkaji permasalahan dengan melakukan analisis kebutuhan pembelajaran di sekolah untuk menentukan perlu atau tidaknya paket pembelajaran yang dapat membantu guru dalam memahami dan menguasai kompetensi analisis kebutuhan pembelajaran. Selain itu, model pengembangan berbasis kelas dan produk juga melibatkan tenaga ahli yang sesuai dengan klasifikasi akademiknya, di luar dari lembaga yang memiliki tenaga akademik tetap.

Prosedur penelitian ini merujuk pada model pengembangan Rowntree. Pertama, tahap perencanaan yang meliputi analisis kebutuhan dan perumusan tujuan pembelajaran. Kedua, tahap pengembangan meliputi pengembangan topik, penyusunan draf dan produksi prototype produk yang akan digunakan untuk belajar siswa. Penyusunan draf dilakukan dengan penulisan format naskah (storyboard). Penulisan format naskah (storyboard) merupakan proses menuangkan materi yang sudah disusun dalam Garis Besar Isi Media (GBIM) dan dijabarkan dalamJabaran Materi (JM) ke dalam suatu format sajian tertentu dengan bahasa penyampaian dan istilah teknis yang telah dipahami dan disepakati bersama antara penulis naskah dengan pengembang. Ketiga, tahap evaluasi yang meliputi self evaluation, expert review, face to face tryout dan field test.

\section{HASIL DAN PEMBAHASAN}

\section{Tahap Analisis Kebutuhan}

Tahap analisis kebutuhan dilakukan pada bulan Juli 2014 dengan cara observasi di kelas VIII SMP Negeri 3 Rangkasbitung. Observasi dilakukan untuk melihat suasana kegiatan belajar mengajar di kelas. Pada akhir kegiatan observasi, peserta didik diberikan selembar kertas dan menuliskan satu mata pelajaran yang paling tidak disukai beserta alasannya.

Dari hasil jawaban peserta didik dalam satu kelas, sebagian besar memilih mata pelajaran 
IPS sebagai perlajaran yang kurang atau paling tidak disukai. Alasan yang dituliskan beragam, di antaranya guru IPS di kelas terlalu serius, penyampaian pelajaran masih bersifat konvensional, guru kurang memberikan kesan yang baik, cara penyampaian materi yang kurang menarik perhatian peserta didik, pembelajaran kurang interaktif, dan materi yang kurang menarik dan terlalu lama.

Setelah melakukan observasi, analisis kebutuhan dilanjutkan dengan melakukan wawancara terhadap kepala sekolah dan guru yang bersangkutan. Hasil wawancara guru dan kepala sekolah menunjukkan bahwa memang benar guru yang bersangkutan kurang menarik perhatian peserta didik dalam penyampaian materi. Akibatnya, ketertarikan peserta didik dalam proses pembelajaran IPS berkurang dan tentunya berdampak pada hasil belajar.

Hal lain yang ditemukan saat mewawancarai guru dan kepala sekolah di antaranya (a) banyaknya masalah belajar yang dihadapi peserta didik, (b) media pembelajaran yang digunakan kurang maksimal karena masih berbasis pada buku teks yang ada, (c) lingkungan sekolah dan guru belum memungkinkan dalam membangun semangat belajar peserta didik, (d) mayoritas guru mata pelajaran IPS sudah memiliki komputer pribadi dan mampu mengoperasikan komputer sehingga memungkinkan untuk memberikan beberapa strategi pembelajaran serta media pembelajaran berbasis IT, serta (e) mayoritas peserta didik sudah bisa mengoperasikan komputer namun belum memiliki komputer secara pribadi sehingga belum memungkinkan dilakukannya pembelajaran berbasis komputer secara mandiri.

Berdasarkan masalah yang ditemukan saat analisis kebutuhan, maka untuk mengatasinya dapat dikembangkan paket pembelajaran IPS berbasis masalah yang terdiri dari buku siswa, buku guru, media pembelajaran, serta kumpulan evaluasi untuk mengukur keberhasilan belajar peserta didik.

Tahap Analisis Instruksional

Tahap analisis instruksional dilakukan agar produk paket pembelajaran yang dihasilkan sesuai dengan kurikulum yang berlaku dan karakteristik peserta didik dengan lingkungannya.

\section{Tahap Pemilihan Materi}

Pada tahap ini dipilih materi-materi pembelajaran yang relavan dengan kurikulum yang ada dan disesuaikan dengan kompetensi dasar yang ada. Materi dan kompetensi dasar tersebut kemudian dihubungkan dengan masalah yang berkaitan dengan kehidupan dan lingkungan peserta didik. Hasil pengembangan dan masukan dari berbagai pihak maka dipilih materi proses persiapan kemerdekaan Indonesia, pranata sosial dalam kehidupan masyarakat, serta permasalahan kerja.

\section{Tahap Pemilihan Media}

Dalam mengembangkan media pembelajaran pada paket IPS berbasis masalah ini menggunakan media satu arah yang hanya digunakan oleh guru pada saat proses pembelajaran. Perangkat lunak (software) yang dipilih untuk membuat media ini adalah Articulae Storyline. Software ini menggabungkan sistem presentasi yang umunya digunakan pada Microssoft Office Power Point serta bentuk gerak animasi pada Macromedia Flash. Software ini diharapkan dapat efektif dalam menyampaikan pesan materi kepada peserta didik dengan menyenangkan.

\section{Pembuatan Story Board}

Pembuatan story board diperlukan agar langkahlangkah dalam pembuatan paket pembelajaran IPS berbasis masalah tersusun secara sistematis. Selain itu, pembuatan story board juga bertujuan untuk menganalisa materi-materi yang akan ditulis pada buku siswa dan buku guru.

\section{Hasil Uji Kelayakan Paket Pembelajaran IPS Berbasis Masalah}

Dalam uji kelayakan ini, terdapat dua tahap kelayakan, yaitu (a) uji kelayakan secara teoretis dan (b) uji kelayakan secara empiris. Uji kelayakan teoretis melibatkan pakar media, pakar materi dan pakar desain pembelajaran yang kompeten di bidangnya. Sedangkan uji kelayakan secara empiris melibatkan pengguna paket pembelajaran IPS berbasis masalah, yaitu guru dan peserta didik.

a. Uji kelayakan Expert Review

Tahap uji coba ini dilakukan dengan melibatkan bapak Dr. Budiaman sebagai ahli materi, Bapak Cecep Kustandi, M.Pd sebagai ahli media dan Bapak Dr. Robinson Situmorang sebagai ahli desain instruksional. Tabel 1 berikut merupakan hasil rekapitulasi yang didapat dari uji coba ahli

Tabel 1. Hasil Rekapitulasi Review Ahli

\begin{tabular}{ll}
\hline \multicolumn{1}{c}{ Aspek } & Rata-rata (skala 4) \\
\hline Materi & 3,28 (Sangat Baik) \\
Media & 3,52 (Sangat Baik) \\
DesainInstruksionaal & 3,63 (Sangat Baik) \\
\hline Rata-Rata Keseluruhan & 3,47 (Sangat Baik) \\
\hline
\end{tabular}

\section{Uji Kelayakan Pengguna}

Setelah dilakukan uji coba ahli, maka langkah selanjutnya adalah uji coba pengguna secara bertahap 
yaitu face to face dan field test. Hasil ujicoba face to face adalah seperti yang disajikan pada Tabel 2 dan Tabel 3.

Tabel 2. Hasil Rekapitulasi Ujicoba Face to Face

\begin{tabular}{|c|c|c|c|c|}
\hline \multirow{2}{*}{ No } & \multirow{2}{*}{ Aspek } & \multicolumn{3}{|c|}{ Jawaban Responden } \\
\hline & & R1 & $\mathbf{R} 2$ & R3 \\
\hline 1 & $\begin{array}{l}\text { Penggunaan } \\
\text { bahasa }\end{array}$ & sudah baik & baik & baik \\
\hline 2 & $\begin{array}{l}\text { Ukuran } \\
\text { huruf }\end{array}$ & $\begin{array}{l}\text { kurang besar } \\
\text { dan terlalu } \\
\text { rapat }\end{array}$ & $\begin{array}{l}\text { kurang } \\
\text { terbaca }\end{array}$ & kurang besar \\
\hline 3 & Tata letak & $\begin{array}{l}\text { sangat } \\
\text { menarik }\end{array}$ & menarik & $\begin{array}{l}\text { menarik dan } \\
\text { berwarna }\end{array}$ \\
\hline 4 & Butir tes & $\begin{array}{l}\text { tidak terlalu } \\
\text { sulit }\end{array}$ & tidak sulit & tidak sulit \\
\hline 5 & Desain slide & $\begin{array}{l}\text { kurang } \\
\text { menarik, } \\
\text { sebaiknya } \\
\text { ditambahkan } \\
\text { gambar atau } \\
\text { warna yang } \\
\text { lebih menarik }\end{array}$ & $\begin{array}{l}\text { slide sudah } \\
\text { menarik }\end{array}$ & $\begin{array}{l}\text { sudah } \\
\text { menarik, } \\
\text { namun } \\
\text { sebaiknya } \\
\text { ditambahkan } \\
\text { warna yang } \\
\text { lebih banyak }\end{array}$ \\
\hline 6 & $\begin{array}{l}\text { Jenis huruf } \\
\text { pada media }\end{array}$ & $\begin{array}{l}\text { ada beberapa } \\
\text { yang sulit } \\
\text { dibaca }\end{array}$ & $\begin{array}{l}\text { sudah } \\
\text { terbaca }\end{array}$ & terbaca \\
\hline 7 & $\begin{array}{l}\text { Jenis huruf } \\
\text { articulate }\end{array}$ & $\begin{array}{l}\text { ada beberapa } \\
\text { yang sulit } \\
\text { terbaca } \\
\text { karena } \\
\text { kurang tebal }\end{array}$ & $\begin{array}{l}\text { sudah } \\
\text { terbaca }\end{array}$ & $\begin{array}{l}\text { sudah } \\
\text { terbaca }\end{array}$ \\
\hline 8 & $\begin{array}{l}\text { Ukuran } \\
\text { huruf } \\
\text { articulate }\end{array}$ & $\begin{array}{l}\text { ada beberapa } \\
\text { yang sulit } \\
\text { terbaca } \\
\text { karena terlalu } \\
\text { kecil }\end{array}$ & $\begin{array}{l}\text { sudah } \\
\text { terbaca }\end{array}$ & agak kecil \\
\hline
\end{tabular}

Adapun hasil ujicoba field test dilihat dari kemasan serta konten produk adalah pada Tabel 3 berikut.

Tabel 3. Rekapitulasi Hasil Uji Coba Field Test

\begin{tabular}{ccc}
\hline Sekolah & $\begin{array}{c}\text { Rata-rata } \\
\text { (skala 4) }\end{array}$ & Ket \\
\hline SMPN 1 & 3.41 & \\
SMPN 2 & 3.27 & \\
SMPN 3 & 3.20 & Sangat Baik \\
\hline Rata-rata Keseluruhan & 3.29 & \\
\hline
\end{tabular}

Sedangkan untuk hasil ujicoba pretest dan posttest disajikan dalam grafik pada Gambar 2.

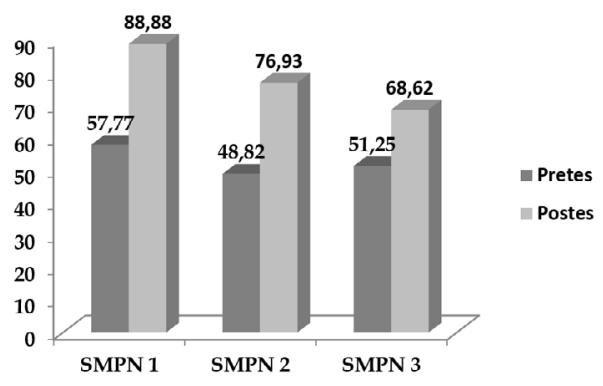

Gambar 2. Grafik hasil pretest dan posttest

\section{Pembahaasan}

Produk yang dikembangkan dalam penelitian ini adalah paket pembelajaran IPS berbasis masalah yang ditunjukkan untuk peserta didik kelas VIII SMP semester 2 pada tiga SMP di Kecamatan Rangkasbitung, Kabupaten Lebak, Banten. Materi yang disajikan dalam produk ini berupa materi pembelajaran IPS dikaitkan dengan masalah yang dihadapi dalam kehidupan sehari-hari. Dengan kata lain, peserta didik dapat dengan mudah memahami dan menerapkan masalah yang dihadapi sehari-hari dikaitkan dengan materi pembelajaran IPS yang diterima di sekolah. Paket pembelajaran IPS berbasis masalah ini terdiri dari buku siswa, buku guru, media pembelajaran dan kumpulan evaluasi.

Adapun kelebihan yang dimiliki oleh hasil pengembangan paket pembelajaran IPS berbasis masalah ini adalah: (a) buku siswa dan buku guru disusun dengan tampilan, konten dan langkah-langkah yang komunikatif sesuai dengan kebutuhan pengguna sehingga dapat mencapai tujuan pembelajaran secara efektif dan efisien; (b) materi dalam paket pembelajaran dapat digunakan secara berurutan maupun acak; (c) materi yang disajikan dalam paket pembelajaran IPS berbasis masalah ini mengacu pada kurikulum dan analisis kebutuhan sehingga dapat membantu pengguna dalam mencapai tujuan pembelajaran yang ditetapkan; (d) paket pembelajaran dilengkapi dengan evaluasi tes dan nontes untuk mengukur pencapaian hasil belajar kognitif, afektif, dan psikomotor untuk mengukur pencapaian hasil belajar setelah menggunakan paket pembelajaran IPS berbasis masalah dalam proses pembelajaran; (e) pembelajaran dapat terkontrol karena dalam penggunaan paket pembelajaran terdapat langkahlangkah masalah dan memungkinkan peserta didik yang berbeda kecepatan belajarnya menjadi lebih teratur; (f) paket pembelajaran dapat memberikan wewenang kepada peserta didik dan guru dalam memilih masalah yang berkaitan dengan kehidupan sehari-hari dengan materi pembelajaran; serta (g) telah dilakukan revisi secara menyeluruh sesuai dengan langkah-langkah model pengembangan yang dipilih sehingga produk yang dihasilkan telah memenuhi analisis kebutuhan yang dilakukan.

Kekurangan yang dimiliki oleh hasil pengembangan paket pembelajaran IPS berbasis masalah ini adalah: (1) membutuhkan perangkat listrik, komputer beserta LCD Projector untuk menampilkan media articulate selama proses pembelajaran sehingga jika lembaga tidak memiliki 
fasilitas tersebut maka proses pembelajaran belum optimal; (2) semua komponen paket pembelajaran harus digunakan secara optimal sehingga jika salah satu komponen tidak digunakan, maka tujuan pembelajaran yang dicapai belum optimal; serta (3) materi yang digunakan dalam paket pembelajaran hanya materi tertentu sesuai dengan kebutuhan. Oleh karena itu, pengembangan materi dalam paket pembelajaran dapat dilanjutkan.

\section{PENUTUP}

\section{Kesimpulan}

Berdasarkan deskripsi yang telah dikemukakan mengenai prosedur pengembangan dan hasil pengembangan yang didapat, maka dapat diambil kesimpulan bahwa paket pembelajaran IPS berbasis masalah untuk kelas VIII SMP dapat diterima dengan baik dikalangan pengguna maupun ahli yang menjadi sasaran dalam pengembangan ini. Hal ini didasarkan pada proses pengembangan yang telah mengikuti alur dan prosedur pengembangan, serta hasil pengembangan yang telah melalui tahap uji coba ahli materi, ahli media dan ahli desain instruksional. Selain itu, tahap uji coba juga telah melalui tahap uji coba one-to-one dan uji coba kelompok besar.

Berdasarkan hasil uji coba tersebut, paket pembelajaran IPS berbasis masalah ini memperoleh penilaian dari ahli sebesar 3,47 dan penilaian dari pengguna 3,41 yang tergolong dalam kriteria sangat baik berdasarkan skala penilaian yang telah ditentukan sebelumnya.

Berdasarkan hasil evaluasi efektivitas pembelajaran paket pembelajaran IPS berbasis masalah setelah peserta didik mengerjakan tes akhir didapatkan hasil yang menunjukkan angka rerata pencapaian sebesar78,15. Adapun kriteria minimum pencapaian tujuan pembelajaran yang ditetapkan adalah sebesar 72. Dengan demikian, dapat dikatakan paket pembelajaran IPS berbasis masalah memberikan kontribusi positif bagi pembelajaran IPS

\section{Saran}

Berdasarkan kesimpulan dan implikasi yang telah diuraikan, berikut ini adalah beberapa saran yang dapat diberikan.

Pertama, bagi peserta didik kelas VIII SMP diharapkan untuk mendukung paket pembelajaran ini dengan benar-benar menggunakannya secara maksimal, sesuai dengan petunjuk penggunaan dan kesepakatan dengan guru.

Kedua, bagi pengajar mata pelajaran IPS, baik saat ini maupun kedepannya agar dapat memanfaatkan paket pembelajaran ini selama materi yang disajikan masih relevan. Berikanlah kontribusi dengan meng-update materi jika diperlukan.

Ketiga, bagi lembaga pendidikan dalam hal ini SMP di kecamatan Rangkasbitung agar memperhatikan berbagai keperluan teknis maupun nonteknis demi kelancaran penerapan paket pembelajaran ini, baik bagi peserta didik maupun bagi guru. Diperlukan dukungan untuk pengembanganpengembangan konten materi berikutnya atau mata pelajaran lainnya.

Keempat, bagi peneliti atau pengembang selanjutnya, disarankan agar terus melakukan peningkatan kualitas terhadap proses pengembangan paket pembelajaran, khususnya media pembelajaran, buku teks dan kumpulan evaluasi. Peningkatan kualitas lebih baik dari segi pembelajaran/media instruksionalnya maupun dari segi teknis medianya untuk menghasilkan produk-produk yang lebih inovatif dan kreatif.

\section{DAFTAR PUSTAKA}

Asep, J. (2012). Evaluasi pembelajaran. Yogyakarta: Multi Pressindo.

Azhar, A. (1997). Media pembelajaran. Jakarta: Grafindo.

Burke, K. (2009). How to access authentic learning. London: SAGE.

Depdiknas. (2006). Peraturan Menteri Pendidikan Nasional Nomor 22 tahun 2006 tentang Standar Isi. Jakarta: Depdikbud.

Emzir. (2012). Metodologipenelitian pendidikan kuantitatif dan kualitatif. Jakarta: Rajawali Pers.

Grondlund, E.N. (2009). Measurement and evaluation in teaching. State Street, New York: Macmillan.

Gustafson, K.L. (2002). Survey of instructional development models. Michigan: Clearing House on Information Resources Syracuse University.

Kapfer, P.G. et all. (2010). Learning packages in American education. Chicago: University Of Chicago Press. 2010.

Khaerudin.,\& Rusmono. (2007). Ragam penelitian dalam teknologi pendidikan. Jakarta: PPs UNJ.

Kumari, V., et. all. (2011). Methods of teaching social studies. New Delhi: Dynamic Printers.

Kurniawan, J. (n.d). Modul Articulate. Diakses dari http;//slideshare.net/JajangKurniawan1/ modul-articulate pada 17 Maret 2105.

Miarso, Y. (2007). Menyemai benih teknologi pendidikan. Jakarta: Kencana.

Michaelis. (1957). Social studies for children in a democracy. Washington: Prentice-Hall.inc. 
Molenda, M., \& Januszewski, A. (2008). Educational technology: A definition with commentary. New York: Lawrence Erlbaum Associates.

Reigeluth, C.M.,\& Chellman, A.A. (2009). Instructional design theories and models. New York: Madison Ave.

Rowntree, D. (1994). Preparing materials for open, distance, and flexible learning. London: Kogan Page.

Rusman. (2010). Model-model pembelajaran. Jakarta: Rajawali Pers.

Savin, M., et.al. (2006). Foundation of problem-basep learning. New York: Open University Press Imprint.
Seels, B.,\& Richey. (1994). Teknologi pembelajaran; definisi dan kawasannya. Washington DC: AECT. Siregar, E., dkk. (2010). Teori belajar dan pembelajaran. Jakarta: Ghalia Indonesia.

Sitepu, B.P. (2012). Penulisan buku teks pelajaran. Jakarta: Rosda.

Suparman, A. (2010). Desain instruksional. Jakarta: Universitas Terbuka.

Litbang. (2002). UU No 18 Tahun 2002. Diunduh dari http://www.litbang.depkes.go.id/sites/ download/regulasi/uu/UU_No._18_Th_2002_ danPenjelasannya.pdf pada 20 Juli 2014.

Pearson. (n.d.). Learning. Diakses dari http://www. lencd.org/learning pada 30 November 2014) 